\title{
PROBLEM (A)CZASOWOŚCI BOGA
}

\begin{abstract}
Streszczenie. W artykule tym rozważana jest kwestia (nie)zmienności Boga, której „pochodną" - biorąc pod uwagę stwierdzenie Arystotelesa, że „substratem” czasu jest ruch jest tytułowy problem (a)czasowości Boga. Aby uwyraźnić i uchwycić wiążące się z tymi zagadnieniami trudności i dylematy, odwołano się do teologii chrześcijańskiej, a w szczególności do problematyki stworzenia, objawienia, a także - co się z tym wiąże - wcielenia oraz zbawienia. Wyprowadzono wniosek, że należy przyjąć, iż w Bogu realizuje się zupełnie inna niż kauzalna zasada ruchu, stąd też i struktura Jego zmienności („Boski czas”) musi być radykalnie odmienna. Ten domniemany rodzaj Boskiej czasowości można nazwać czasem absolutnym i uznać, że przypomina on coś, co z naszej ludzkiej perspektywy da się za Heglem określić teraźniejszą obecnością.
\end{abstract}

Słowa kluczowe: Bóg, zmienność, niezmienność, historyczność, metafizyczność, czasowy, aczasowość, duch, tożsamość, różnica.

1. Wstęp. 2. Dwoista perspektywa. 3. Dialektyczny punkt widzenia. Hegel. 4. Specyfika ducha. 5. Historyczność stworzenia a zmiana w Bogu. 6. Immanencja Boga a natura ludzkiego poznawania. 7. Zakończenie.

\section{WSTĘP}

W artykule tym rozważam kwestię (nie)zmienności Boga, której "pochodną" - biorąc pod uwagę stwierdzenie Arystotelesa, że „substratem" czasu jest ruch ${ }^{1}$ - jest tytułowy problem (a)czasowości Boga. Aby uwyraźnić i uchwycić wiążące się z tymi zagadnieniami trudności i dylematy, odwołuję się do teologii chrześcijańskiej (głównie katolickiej), a w szczególności do problematyki stworzenia, objawienia, a także - co się z tym wiąże - wcielenia oraz zbawienia.

1 Dokładniej Arystoteles pisał: „, substrat czasu, czyli ruch”. Arystoteles, Fizyka, tłum. z grec. K. Leśniak, w: tenże, Dzieła wszystkie, t. 2, PWN, Warszawa 1990, 114. 
Zagadnienie zmienności (czasowości) względnie niezmienności (aczasowości) Boga jest o tyle istotne, że Bóg rozumiany jako byt absolutny (samoistny, pierwotny, samodzielny i niezależny ${ }^{2}$ ) ujmowany jest w tradycji teologiczno-filozoficznej jako byt doskonały. Każda zaś zmiana polega m.in. na różnicy stanów. Stąd powstaje na przykład pytanie, czy Bóg podlegający zmienności, zmieniałby także swą doskonałość, czy też może byłaby to zmiana zachowująca Jego absolutną doskonałość?

Tytułem wstępu dodam jeszcze, że w swoich analizach posiłkuję się głównie myślą dialektyczną (Jakob Böhme, Georg Wilhelm Friedrich Hegel), a więc odmiennie od „klasycznego teizmu” (św. Augustyn czy św. Tomasz z Akwinu), który w swych analizach opierał się na logice klasycznej narzucającej odmienną - bardziej statyczną ontologię Boga. Bliższy jest mi dialektyczny punkt widzenia.

\section{DWOISTA PERSPEKTYWA}

Jako ontologiczny problem dotyczący objawienia Joseph Ratzinger wskazuje na przeciwstawienie metafizycznej i historycznej interpretacji tej kategorii. Historycznie biorąc, objawienie jest częścią czasowego procesu zbawiania człowieka przez Jezusa Chrystusa; metafizycznie zaś rozumiane jest ono jako "pozaczasowa mistyka” dostępna „od zawsze”, zrealizowana odwiecznie ${ }^{3}$. Czy takie przeciwstawienie „dialektycznego" (historycznego) i metafizycznego punktu widzenia jest istotną trudnością w ontologii Boga?

Mamy tu raczej dwie odmienne perspektywy, które mogą współistnieć ze sobą. $Z$ jednej strony jest to perspektywa Boga, który - jak można to rozumieć - jest odwieczną aktualnością trwającą

2 By przywołać znane określenia bytu absolutnego z Ingardenowskiego Sporu o istnienie świata. R. Ingarden, Spór o istnienie świata, t. I, PWN, Warszawa 1987, 124.

3 J. Ratzinger, Rozumienie objawienia i teologia historii według Bonawentury, Wydawnictwo KUL, Lublin 2014, 52-53. 
niezmiennie w swej doskonałości, a z drugiej - człowieka, który żyje $\mathrm{w}$ stworzonej rzeczywistości historycznej i z konieczności postrzega ją jako szereg procesów rozciągniętych w czasie - dotyczy to także ujmowania Boga i Jego relacji do człowieka. Nie chcę przez to powiedzieć, że czas fizyczny i historia świata (w tym historia zbawienia) jest złudzeniem, a jedynie to, że u Boga wszystko jest „odwiecznie rozstrzygnięte” - jest absolutną aktualnością. Być może taka „dwoistość perspektyw" jest ontologicznie niepokojąca, ale, doprawdy, trudno wyobrazić sobie, aby absolutna samoświadomość Boga postrzegała siebie najpierw jako Boga bez stworzenia, potem siebie stwarzającą, a w dalszej kolejności siebie wcieloną i zbawiającą etc.

„Niepokój ontologiczny” wiąże się z pytaniem, która perspektywa (czasowa czy pozaczasowa) jest prawdziwa, tj. jaki faktycznie jest byt. Czy jest on jak nieogarnialny jednym ludzkim spojrzeniem (myślą) obraz, który w pojedynczym aktualnym akcie jest w stanie widzieć tylko Bóg, czy też raczej jest niczym rozwijający się rulon z taśmą, której zawartość Bóg zna od początku, a która realnie podlega procesowi rozwijania. Słowem: czy chodzi tu o gnozeologiczna (poznawczą) ,przewagę” Boga (przypadek rozwijającego się rulonu) czy o poznawczą ułomność człowieka (przypadek ogromnego gotowego obrazu)? A może ani o jedno, ani o drugie - tylko o dwie „równoległe” rzeczywistości - Boską i ludzką? W takim wypadku jednak powstaje problem ich „przecięcia się” oraz „Ockhamowy dylemat”, czy aby nie jest to mnożenie bytów ponad konieczność. Jak w przywołanym wyżej dziele zauważa Ratzinger, uznanie - przyjmowanej przez Tomasza - „teorii wiecznego stworzenia” (a tym samym - wiecznego objawienia oraz zbawienia) jest wątpliwe z punktu widzenia ortodoksyjnego chrześcijaństwa, dla którego świat rozwija się po linii czasu, czyli ma dzieje, w których przemijają i pojawiają się coraz to nowe zdarzenia aż do Sądu Ostatecznego. Niemniej, jak sądzę, ontologicznie „męczący” jest problem, czy wraz ze światem także Bóg ma swoje dzieje, w których „przydarzają” mu się coraz 
to nowe zdarzenia i okoliczności. Na przykład to, że stworzył On świat wraz z człowiekiem, w którym to świecie w pewnym momencie objawił się pod postacią Jezusa Chrystusa i Jego zbawczego dzieła. By uniknąć wspomnianej wyżej dwoistości, trzeba by opowiedzieć się za Bogiem historycznym, ewoluującym. I można to zrobić bez uszczerbku dla Boskiej absolutności. Błędem „metafizycyzmu” (jako przeciwieństwa dialektyki) jest utożsamienie absolutu $\mathrm{z}$ bytem niezmiennym, całkowicie statycznym (,zamrożonym”, „blokowym”). W tym kontekście trzeba powiedzieć, że naturę absolutu zupełnie nieadekwatnie ujmował Leszek Kołakowski w eseju Kaptan ibłazen ${ }^{4}$. Absolutność utożsamia on bowiem z maksymalną entropią, wyrównaniem wszelkich napięć, zniesieniem asymetrii i zróżnicowania. Taki „martwy” absolut mógł przedstawić chyba tylko materialista-ateista, który nie zna - albo raczej celowo pomija - „teologiczne realia" Boga w Trójcy Jedynego; Boga, który nie tylko jest maksymalną koncentracją „energii” duchowej, lecz zarazem - wewnętrznie zróżnicowanym bytem o asymetrycznych „członach” (hipostazach), między którymi panuje najwyższe duchowe napięcie - nieskończona Miłość. Tak więc z punktu widzenia chrześcijaństwa Kołakowski ignoruje rzeczywistość Trójjedynego Boga. Przechodząc zaś na ogólniejszy poziom prezentacji idei absolutu można zacytować słowa Hegla: „Ten niepokój tkwi w nim samym [w bycie absolutnym - M.モ.] jako negacja negacji i niepokój ten określa się bliżej jako aktywność”’

Odwieczną aktualność Boga należy raczej postrzegać - jak to już sugerowałem wyżej - noetycznie, tj. jako absolutną przedwiedzę - jako odwiecznie aktualne ogarnięcie boskim umysłem całości dziejów, które poza tym są obiektywnym procesem, w którym bierze udział sam Bóg. Dodatkowo odwieczną aktualność Boga można

4 L. Kołakowski, Kapłan i błazen, w: Pochwała niekonsekwencji. Pisma rozproszone z lat 1955-1968, przedmowa, wybór i opracowanie Z. Mentzel, Warszawa 1989.

5 G.W.F. Hegel, Wykłady z filozofii religii, t. 2, Wydawnictwo Naukowe PWN, Warszawa 2007, 549. 
pojmować także ontologicznie w taki sposób, że oto Boga uczestniczącego w procesie światowym ujmujemy jako byt od początku „W sobie i dla siebie” ze zrealizowaną odwiecznie własną istotą. Bógw przeciwieństwie do człowieka jest odwiecznie „u siebie”. Proces światowy (ewolucja, historia) nie zmieniają istoty Boskiej. Jeśli chodzi o kwestię stawania się Boga wraz z ustanawianiem przez Niego bytu stworzonego, to Karl Rahner dopuszcza - zgodną z powyższym rozumieniem - zmianę w Bogu, która nie narusza Jego najgłębszej istoty: „Zgodnie $\mathrm{z}$ wiarą tym pierwotnie danym zjawiskiem jest właśnie samoogołocenie się, stawanie się, kénosis i génesis samego Boga, który może się stawać o tyle, że ustanawiając to, co powstaje jako inne, sam staje się tym powstającym, nie musząc przy tym stawać się w swojej najgłębszej, pierwotnej, własnej istocie"6.

Bóg jest zawsze tym samym Bogiem ze wszystkimi swoimi możliwościami (zasobem Miłości), decyzjami i totalną wiedzą. Inaczej zaś jest z „człowiekiem w czasie” - tu dochodzi do radykalnej przemiany (czy raczej radykalnych przemian): wypędzenie z raju, zbawienie, Sąd Ostateczny. Żadne z tych zdarzeń nie zmienia esencji Boga - nie dotyka odwiecznego rdzenia Biskiego istnienia; zmienia za to istotę człowieka i jego status kosmiczno-bytowy. Taki punkt widzenia potwierdzają ci mistycy lub „dialektycy”, którzy rzeczywistość Boską rozpatrują jako proces. Jakob Böhme np. pisze wprost o narodzinach Boga z Nicości („Bezdna”, „Bezgrunt”- niem. Ungrund). Tyle tylko, że ta Nicość nie jest absolutną nicością ontyczną, ale Boską Wolą, Chceniem, które pożąda samego siebie, a pożądając, „wchodzi” w samego siebie jako w Centrum, aby na powrót z siebie „wyjść” (w formie innobytu - stworzenia), by wreszcie - zataczając „dialektyczne koło" - powrócić do siebie w jakimś mistycznym zjednoczeniu ze stworzoną naturą i zbawionym oraz zmartwychwstałym człowiekiem. Dialektyczny punkt widzenia jest tutaj niezbędny. Jeśli bowiem

6 K. Rahner, Podstawowy wykład wiary. Wprowadzenie do pojęcia chrześcijaństwa, Instytut Wydawniczy PAX, Warszawa 1987, 183. 
Bóg - w najbardziej choćby metaforycznym sensie - jest „życiem” (ruchem), to potrzebuje on „swojej nicości”: Paul Tillich zwraca uwagę, że pierwiastek boski „(...) jako życie zakłada nie-bycie”. Nicość ta jednak nie może być absolutna - być czymś, co byłoby zupełnie poza substancją Boga; musi to być jedynie innobyt Boskiej Istoty („Jego nicość", coś co - zupełnie paradoksalnie - zaprzeczając Bogu i przeciwstawiając się Jego istocie, jednocześnie afirmuje Jego istnienie i esencję. To musi być po prostu On sam w swym własnym wewnętrznym zróżnicowaniu.

\section{DIALEKTYCZNY PUNKT WIDZENIA. HEGEL}

Pozostający pod wpływem Böhmego, Hegel także patrzy na Boga ewolucyjnie i dialektycznie. „Absolutna, wieczna idea” jest - z jednej strony - „Bogiem samym w sobie i dla siebie w swej wieczności przed stworzeniem świata, poza światem" ${ }^{8}$. Z drugiej jednak - jest ona „stworzeniem świata”, który to świat (rozpadający się na fizyczną przyrodę i skończonego ducha) jest innobytem Boga - „czymś innym, założonym zrazu poza Bogiem”. Różnica w Bogu jest źródłem ruchu: „duch jest odróżnianiem siebie, zakładaniem odróżnionych [stron]"10. Taka pierwotna „nieodpowiedniośc" tkwi w duchowości jako jej zasada. I nie może ona zniknąć - „gdyby znikła, wówczas znikałby pra-podział ducha, jego żywość; w ten sposób przestawałby on być duchem"11. Jednak mimo tej różnicy i nieodpowiedniości Bóg sam $z$ siebie jest ruchem $w$ kierunku pojednania ze sobą tego „obcego” (piszę „obcego” w cudzysłowie, gdyż przecież to sam Bóg powołał go $\mathrm{z}$ siebie do istnienia - można tu zatem mówić o samoalienacji).

7 P. Tillich, Pytanie o Nieuwarunkowane, Wydawnictwo Znak, Kraków 1994, 124.

8 G.W.F. Hegel, Wykłady z filozofii religii, t. 2, Wydawnictwo Naukowe PWN, Warszawa 2007, 224.

9 Tamże, 225.

10 Tamże, 288.

11 Tamże. 
Bóg poprzez stworzenie dzieli się, lecz powraca do siebie samego: "Jest to droga, proces pojednania, za pośrednictwem którego duch zjednoczył ze sobą to, co odróżnił od siebie w swoim rozszczepieniu (in seiner Diremition), w swoim pra-podziale (seinem Urteil), i w ten sposób jest Duchem Świętym, duchem w swojej gminie"12. Rysuje się tu zatem perspektywa trynitarnego odczytania Boskiego samoruchu: Ojciec jako pierwotna idea sama w sobie i dla siebie, Syn jako innobyt (dokładniej: jako Bóg wobec innobytu ${ }^{13}$ ), Duch Święty jako pojednanie Boga i tego, co mu „obce”. W ten sposób samoruch Boga, który objawia się - poprzez stworzenie świata - w sferze transcendencji, znajduje swoje podstawy w czystej Boskiej immanencji - w wewnętrznym ruchu troistej natury Boga. Jak pisze Hegel: „(...) ogólny duch zakłada całość tego, czym jest, siebie samego w trzech określeniach, rozwija się, realizuje i dopiero na końcu ma ostateczną postać, która zarazem jest jego przesłanką. Jest on jako całość w tym, co pierwsze, zakłada siebie [jako przesłankę] i jest również tylko na końcu"14. Mamy tu zatem klasyczne dialektyczne koło - koło, którego Hegel z pewnością nie uznałby za niedogodność „onto-logiczną”, lecz za wyraz wejścia na wyższy poziom poznania - poziom wiedzy absolutnej, czyli wiedzy o Absolucie. Dodać tu jeszcze wypada, że takie zapętlenie wskazuje także i na to, że cały ten „ruch w Boskiej Istocie” dokonuje się poza znanym nam czasem. Można powiedzieć, że to nie wszechświat - jak chcą niektórzy kosmologowie i astrofizycy jest „blokowy”, lecz Bóg, który w swym - niepojmowalnym dla nas w zasadzie - ruchu jest jakby cały od razu.

Zresztą - na co zwraca uwagę Hegel - jest tu pewna dwoistość w naszym pojmowaniu Boskiej rzeczywistości (pytanie: czy dwoistość tę należy przypisywać także Bogu samemu?). Z jednej bowiem

12 Tamże.

13 Trudno jest bowiem traktować Syna jako innobyt Ojca - choćby ze względu na Ich współistotność.

14 G.W.F. Hegel, Wykłady z filozofii religii, t. 2, dz. cyt., 225. 
strony „boska historia jest poza swiatem, poza przestrzenia (raumlos), poza skończonością - jest to Bóg zgodnie z tym, jak istnieje on sam w sobie i dla siebie"15, z drugiej zaś - mamy Boską historię jako dziejącą się realnie w świecie: ,jest to Bóg w zupełnym istnieniu (im volkommenen Dasein)"16. Z tego, co pisze Hegel, można wnosić, że odpowiedź na postawione w nawiasie pytanie powinna brzmieć: tak, to realna dwoistość Boskiej rzeczywistości, a nie tylko nasz sposób pojmowania Boga. Tyle tylko, że pojawia się tu trudność następująca: Bóg sam w sobie i dla siebie (Bóg poza czasem, „jako wieczna idea, w elemencie wieczności"17) zdaje się nie być absolutny, skoro do swojego „zupełnego istnienia” potrzebuje objawienia się w historycznym świecie. Wieczność Boskiego czasu „rozwija się i rozkłada na przeszłość, teraźniejszość i przyszłość"18. Boska ziemska historia nie jest już wszechobecną teraźniejszością, lecz - jako skażona przeszłością ${ }^{19}$ - ma byt, „który jest zdegradowany do pozoru”20. Mamy tu charakterystyczny dialektyczny motyw „wywyższenia” (osiągnięcie pełni) poprzez „upadek” (degradację odwiecznej teraźniejszości do przemijalności). Jednak ten ruch Boskiej natury w kierunku degradującego ją innobytu nie musi być interpretowany jako przejaw słabości Boga, lecz jako - wynikający z Boskiej wszechmocy - wolny gest Miłości uczyniony w kierunku stworzenia.

Można powiedzieć, że Hegel wraz z Böhmem odkryli (a już z pewnością wyraźnie sformułowali) coś, co nazwałbym spiżowym prawem ruchu bytu jako takiego (ontologicznej totalności, absolutu - a w ujęciu teistycznym - Boga). Trudno bowiem z perspektywy „ontologii maksymalnej”, czyli takiej, która ujmuje byt w jego

15 Tamże, 226.

16 Tamże.

17 Tamże.

18 Tamże.

19 „Jako przejaw jest ona bezpośrednim istnieniem (Dasein), które też zarazem jest zanegowane; jest to przeszłość". Tamże.

20 Tamże. 
totalności - w jego odwiecznym zawsze i wszędzie, inaczej postrzegać ruch całości (absolutu, Boga) jak tylko jako samoruch podlegający dialektycznemu prawu podwójnej negacji. Zgodnie z tym ostatnim pierwotna tożsamość i równość ze sobą bytu jako takiego (Boga) zostaje - na mocy wewnętrznej zasady ruchu absolutu - przekroczona poprzez wyjście $z$ samego siebie (pranegacja) ${ }^{21}$ i ukonstytuowanie innobytu po to, aby, negując ten ostatni - negując owo immanentne rozdwojenie (negacja negacji) - powrócić do samego siebie w swej pierwotnej i całkowitej tożsamości. Oddajmy głos Heglowi z Nauki logiki: "Jeśli więc rozwijanie absolutu rozpoczyna się od jego absolutnej identyczności i przechodzi następnie do atrybutu, a od atrybutu do modusu, to objęło ono w ten sposób wszystkie swoje momenty (...) rozwijanie to nie ma do czynienia wyłącznie z tym, co zewnętrzne, a modus jest nie tylko najbardziej krańcową zewnętrznością, lecz ponieważ jest pozorem jako pozór, przeto okazuje się powrotem do siebie, jest ową rozwiązującą samą siebie refleksją, którą absolut jest jako absolutny byt"22. Można rozumieć to tak, że pierwotna absolutna identyczność Boga z samym sobą przechodzi w Jego atrybut, którym jest to, aby On założył siebie jako coś innego (jako pozór, innobyt, modus), które to inne - będąc zarazem samym Bogiem - powraca do swojego zadomowienia w swej całkowitej identyczności - równości z sobą samym. Zgodnie z tym, co powiedziano wyżej, prawo negacji negacji można by nazwać prawem „wyjścia i powrotu” - lecz takiego wyjścia i powrotu, które - paradoksalnie (?) - cały czas pozostaje u siebie.

Zaproponowaną przez Hegla wizję samoruchu Boga można kwestionować. Po co Bóg miałby w ogóle to robić? Jednakże pozostawienie Boskiej istoty w jej niezróżnicowanej prostocie trudno byłoby

21 Która nie może być momentem czysto negatywnym, lecz raczej samoafirmacją absolutu (Boga), jego poznawczym (myślowym, duchowym) rozdwojeniem się na samowiedzę, która jest swoim własnym przedmiotem.

22 G.W.F. Hegel, Nauka logiki, t. 1. PWN, Warszawa 1967, 68-69. 
pogodzić z chrześcijańską ontologią i teologią stworzenia. Wprawdzie stworzenie można pojmować metafizycznie, a nie historycznie, tj. jako odwieczny, ponadczasowy stan. Tyle tylko, że i w tym wypadku nieuchronne jest przyjęcie różnicy między Bogiem a stworzeniem ich wzajemnej transcendencji.

\section{SPECYFIKA DUCHA}

Opisany powyżej ruch własnego zakładania, wyjścia poza siebie (negacja) i negacji tego - pozostającego wszak cały czas u siebie „wygnania” może być właściwy tylko duchowi. Tylko bowiem wola może chcieć rozpoznać w sobie różnicę (samowiedza), utrwalić ją jako innobyt, a potem ją znieść jako moment swego własnego rozwoju. Materia jest w tym względzie całkowicie bierna. Zmieniają się jej postacie, lecz nie można uznać, iż zmienia ona sama siebie z siebie samej. A przecież tak musi być, jeśli brać pod uwagę totalność bytu gdyż poza bytem nie ma już nic. Inaczej jeszcze: byt absolutny jako pierwotnie (co nie znaczy "uprzednio” w sensie czasowym) całkowicie tożsamy z sobą samym musi (po to, aby zainicjować swój ruch nie może on wszak być „martwym bezruchem”) mieć sam w sobie możliwość różnicującego samoodniesienia. Bezwładna materia zaś nie jest w stanie odnieść się do siebie samej, gdyż jest poznawczo bierna - brak jej uwagi oraz woli. Jej domeną jest sztywna deterministyczna zmienność lub - biorąc pod uwagę poziom kwantowy - przypadkowość (nieoznaczoność, niepełna określoność, statystyczność, potencjalność ${ }^{23}$. Jednakże tak rozumiane zdeterminowanie oraz potencjalność są określeniami czysto zewnętrznymi (jest się determinowanym przez coś, a potencjalnym ze względu na coś). W przypadku absolutu (bytu pierwotnego) musimy mieć zatem do czynienia a autodeterminacją oraz potencjalnością opartą na wolności. Tylko wolna decyzja, celowy świadomy wybór zapewnia bytową autonomię.

23 Jak ma to miejsce w klasycznej kopenhaskiej interpretacji mechaniki kwantowej. 
Można zatem przypuszczać, że tym, co pierwotne, musi być wolny duch - na przykład Böhme'owska Wola, która pragnie samej siebie, czy Heglowski absolut rozwijający z siebie swą własną negację - innobyt, który okazuje się jednak - w jego powrocie do siebie samego z nim tożsamy. Należy do tego dodać, iż w tym samoruchu Boga, nie ma żadnych momentów przypadłościowych, gdyż nie istnieją żadne wpływy zewnętrzne; wszystko jest rozwijaniem się Jego wewnętrznej istoty (u Hegla - jego idei, pojęcia). Wynika stąd, że świat stworzony - choć nie może być z Bogiem utożsamiany - także należy do tej istoty jako jej nieusuwalny składnik. Czy oznacza to, że Bóg musiał stworzyć świat? Można powiedzieć w następujący sposób: nie musial, lecz absolutnie wolna wola uczynienia tego zawarta jest w samej Jego istocie - w Miłości. Jak stwierdza cytowany przez Hansa Ursa von Balthasara Karl Barth: „dla Boga było rzeczą nie tylko stosowną i godną, ale koniecznq, by był On Stwórcą. Skoro odwieczna decyzja Boga została podjęta w całej wolności Jego miłości, to musiat On być Stwórcą"24.

Jako kontrargument do przedstawionego wyżej rozumowania można wysunąć dialektyczną hipotezę, że pierwotnie absolut nie jest totalną tożsamością i równością z sobą samym, lecz „od zawsze” (odwiecznie) zawiera w sobie rozłam, opozycję, przeciwstawność (lub przeciwstawności), które są racją jego pierwotnego ruchu. W materialistycznym ujęciu można by tu myśleć np. o materii i antymaterii lub o przyciąganiu i odpychaniu itp.

W wielu jednak systemach metafizycznych $-\mathrm{z}$ koncepcją Plotyna na czele $-\mathrm{z}$ bytem absolutnym wiązana jest absolutna jedność (pierwotna totalna tożsamość, brak zróżnicowania, niepodzielność i równość samemu sobie). Jeśli uznać tę henologiczną intuicję za trafną - jeśli Jednia jest rzeczywiście tym, co pierwotne - to materia z wielkim trudem, jeśli w ogóle, mogłaby być uznana za substancję, która taką najwyższą jedność przejawia. Do samej istoty materialności

24 H.U. von Balthasar, Teologika 3. Duch Prawdy, Wydawnictwo WAM, Kraków 2005, 378. 
należy bowiem zmienność, która - jako swego motoru - wymaga antagonizmów, przeciwstawności, wprawiających ją w ruch (wspomniane wyżej przyciąganie i odpychanie, a także np. dodatniość i ujemność ładunków elektrycznych, opozycyjność biegunów magnetycznych itp.). I nie zmienia tego faktu to, że także w substancji materialnej da się pomyśleć bardzo wysoki stopień jedności. Można tu np. pomyśleć o zjednoczeniu w osobliwości naszego świata (Wielki Wybuch) czterech podstawowych typów sił fizycznych wymienianych w Modelu Standardowym: oddziaływań silnych, oddziaływań słabych, elektromagnetycznych i grawitacyjnych. Ale przecież ta superunifikacja rozpadła się w końcu bardzo szybko (definitywnie po upływie „ery Plancka” - $10^{-44} \mathrm{~s}$ ). Powody zaś „złamania tej symetrii” mogły być - najogólniej biorąc - dwa: wpływ zewnętrzny (ze strony innych światów składających się na wszechświat) - co wyklucza absolutność i pierwotność świata, lub napięcie wewnętrzne (zakładające jakieś wewnętrzne zróżnicowanie antagonistycznych czynników) - co z kolei uniemożliwia uznanie tego świata za absolutną Jednię.

Inaczej jest - jak się zdaje - z zasadą duchową. Duch bowiem rozumiany jako absolutnie równa sobie samej Wola (Wola, która jest chceniem samej siebie, równością tego, co „pożądane”, z tym, co Jest) mocą swojej wolnej decyzji (wolność jako atrybut bytu Osobowego) może zwrócić się ku temu, co inne, tj. ku temu, co przez pierwotną Myśl zrazu jest tylko pomyślane jako inne. Jeśli zatem myśl henologiczna ma rację, to jedynym Jednym, które zdolne jest przekroczyć granicę własnej absolutnej równości - aby do niej powrócić - może być tylko Duch. Trzeba jednak dodać, że także i w tym wypadku można by postawić zastrzeżenie, że przecież wyjście Woli poza samą siebie także musi mieć jakiś bodziec, a ten polegać by musiał na jakimś napięciu i nierówności. Kluczowe dla odrzucenia tej wątpliwości zdaje się być założenie absolutnej wolności ducha, która wyklucza wszelką heterogeniczność - także tę wewnętrzną - a zarazem gwarantuje możliwość różnicującego ruchu. 


\section{HISTORYCZNOŚĆ STWORZENIA A ZMIANA W BOGU}

Ewolucyjną mistykę (Z)jednoczenia rozwija także w swej diachronicznej koncepcji Boga Pierre Teilhard de Chardin. W Mojej wizji świata relację między Bogiem (Chrystusem) a wszechświatem ujmuje on nie jako statyczną, lecz historyczną właśnie. Opowieść o ewoluujaccym wraz ze stworzeniem kosmicznym Bogu rozpoczyna wszak od "antynomii" - antynomii całkowitej wystarczalności - Bóg jako byt absolutny i doskonały powinien zupełnie sobie wystarczać, a jednakstwarza wszechświat. Skoro zaś Bóg to robi, to można przypuszczać, że wszechświat - jak ujmuje to Teilhard - „przydaje mu czegoś koniecznego". Bóg sam w sobie i dla siebie jest bytem całkowitym, ale możliwa i zgodna z Jego istotą jest jedność Boga ze stworzeniem. Metafizyka, jaką proponuje francuski filozof jest „metafizyką jednoczenia”, czyli jest ontologią procesu, któremu podlega także Bóg. Choć bowiem Bóg immanentnie jest zupełną jednością, to możliwe jest jeszcze zjednoczenie Boga i stworzenia. Proces światowy ujęty jest zatem jako jednoczenie, którego głównym beneficjentem jest byt stworzony (a w szczególności człowiek). Wszakże i dla Boga nie jest on obojętny, skoro go chciał (wspomniana wyżej „antynomia”)25.

Stwarzając, Bóg stawia się jakby w nowej sytuacji. Lecz zanim stworzy transcendencję, także w Jego immanencji zachodzą istotne „zmiany”. Jeden jedyny, niepodzielny Bóg miałby - według „mistyków-ewolucjonistów” - w pewnym momencie „swojej historii” wyodrębnić w sobie - trzy osoby. Kto uznaje historyczność takiej transformacji, ten jako sensowne musi dopuścić także takie np. pytania: Kiedy doszło do tego zróżnicowania? Która z osób Boskich

25 Skoro odwołałem się do Teilharda de Chardina, to należy podkreślić, iż myśl jego w wielu aspektach odchodzi od ortodoksji katolickiej. Niektórzy - np. Dietrich von Hildebrand - zarzucają mu wręcz „nieuleczalną sprzeczność z chrześcijaństwem” - jak chociażby w kwestii nieprzestrzegania radykalnej różnicy miedzy duchem a materią i miedzy ciałem a duszą oraz w wielu innych. D. von Hildebrand, Koń trojański w mieście Boga. Przyczyny kryzysu w kościele katolickim, Warszawa 2000, 181 nn. 
wyłoniła się jako pierwsza? Czy ukonstytuowanie się trzech Osób poprzedzało w czasie stworzenie? Czy postać Boga w trójcy jedynego ma byt wieczny, czy też Bóg powróci kiedyś do swego domniemanego pierwotnego niezróżnicowania? Pytania te - jak widać - są niezwykle kłopotliwe, co sugeruje ontologiczną trudność historycznego traktowania Boga. Wydaje się, że wszystko, co mówimy o Bogu, powinniśmy ujmować w „reżimie metafizycznym”, tj. jako czystą niezmienną aktualność. Bóg stworzył nasz świat wraz z czasem i historią, lecz sam pozostaje w odwiecznej aktualności - poza czasem, który rządzi światem stworzonym. Hegel ujmuje to np. tak: „Lecz aktywność Boga jest w ogóle po prostu tylko jedna i ta sama, nie jest różnorodnością odróżnionych działań, nie jest jakimś Teraz i Potem, jakimś jedno-poza-drugim (ein Aussereinander) itp."26. Przy czym - zdaniem Hegla - nawet przypisywanie Bogu istnienia wiecznego czy odwiecznego jest nie na miejscu. Pytania o odwieczność dotyczą raczej materii, gdyż chodzi w nich o nieskończony czas trwania, a to jest „zła nieskończoność”, którą zajmuje się „czcza metafizyka”. „Gdy tylko - pisze filozof niemiecki - wyobrazimy sobie świat, od razu pojawia się czas, a następnie, za sprawą refleksji - owa nieskończoność czyli wieczność; ale musimy mieć świadomość, że to określenie w ogóle nie obchodzi samego pojęcia" 27. Pogląd Hegla pozostaje w tym względzie niezgodny z rozumieniem Bartha, którego myśl Balthasar streszcza następująco: „odczytuje on stworzenie jako całościową historię zbawienia, ukierunkowaną od rozwoju przyrody na człowieka, a od niego na Chrystusa (creatio continua), przy czym natura jest już zawsze objęta łaską, a czas przyznany stworzeniu jest mu udzielony z odwiecznie trójjedynego czasu i odwiecznie trójjedynych dziejów Boga"28. Niejasne pozostaje przy tym, cóż może znaczyć „odwiecznie trójjedyny(e) czas (dzieje)". Czy mówiąc o trójjedynych dziejach Boga

26 G.W.F. Hegel, Wykłady z filozofii religii, t. 2, dz. cyt., 259.

27 Tamże, 260.

28 H.U. von Balthasar, Teologika 3, dz. cyt., 378. 
rozumiemy ruch w Jego istocie analogicznie do ziemskiej historii, do ewolucji kosmosu? Czy owo „udzielanie” czasu stworzeniu oznacza, że czas stworzenia jest jakimś fragmentem (interwałem) czasu Boga? Jeśli odpowiedź na oba te pytania miałaby być pozytywna, to trudno się z tym zgodzić. Zachodzi bowiem przypuszczenie (wzmacniane np. refleksją Hegla), że ruch, jaki odbywa się w Istocie Absolutnej, nie ma nic wspólnego $\mathrm{z}$ wewnątrzświatowym czasem rządzącym przemianami stworzenia - że samo stwarzanie nie odbywa się w czasie, lecz jest stanem swoistej „bezczasowej dynamiki” właściwej Bogu. Innymi słowy: że stwarzanie to jest częścią istoty Boga i dokonuje się „odwiecznie” lub - jak wolałby może powiedzieć Hegel - jest esencjalnym aspektem ,jednej i tej samej” (nie podzielonej na teraz i potem) aktywności Boga.

My zaś opowiadamy o Bogu historycznie, gdyż perspektywa czasu - ze względu na naturę stworzonego świata - jest dla nas nie do przekroczenia. Wyznawana przez ludzi religia jest historyczna (i to w podwójnym sensie, tj. jako fenomen kultury oraz ze względu na uporządkowanie czasowe jej treści ${ }^{29}$ ), ale - jak można przypuszczać - nie jest taki jej główny przedmiot - Bóg. Może też najbardziej zasadniczą różnicą ontologiczną między Bogiem a stworzeniem jest taka, że to ostatnie jest obarczone czasem; czas zaś jest jednym ze źródeł niedoskonałości i ułomności świata stworzonego. Idzie tu przecież o naturalną zmienność (ruch) jako „substrat czasu”, która nie tylko buduje, lecz także niszczy.

W tym kontekście należy jeszcze zwrócić uwagę na sygnalizowany już problem: czy jakakolwiek zmiana w Bogu nie naruszałaby Jego absolutnej doskonałości? Ponieważ najdoskonalsze nie może stać się doskonalszym, można uznać, że wszelka istotna zmiana stanu w Bogu oznaczałaby Jego samodegradację. Chcąc utrzymać założenie

29 W Rozumieniu objawienia i teologii historii według Bonawentury Ratzinger stale podkreśla historyczność religii chrześcijańskiej w aspekcie jej treści (np. historyczność objawienia (wcielenia), zbawienia etc. 
o zmienności Boga, a zarazem uniknąć tej ostatniej konsekwencji, trzeba by przyjąć, że wszelka zmiana w Bogu ma charakter czysto formalny - jest przekształceniem identycznościowym lub symetrycznym, czyli takim, które w rezultacie daje to samo. Taka ,jałowość" zmienności Boga może budzić słuszne wątpliwości. Jest tu wszak inna jeszcze możliwość interpretacyjna, którą wskazywałem już wcześniej: godzimy się na uznanie ruchu w Bogu jako prowadzącego do swoistej degradacji Jego najdoskonalszego bytowania, lecz zarazem - paradoksalnie - będącego właśnie potwierdzeniem Jego najwyższej doskonałości, tj. całkowicie wolnej decyzji o udzieleniu swej Miłości stworzonemu światu. W teologii biblijnej mówi się o kenozie, czyli o samouniżeniu się boskiego Logosu we wcieleniu. Samouniżenie to polega na wyrzeczeniu się przez Chrystusa okazywania należnej Mu chwały, posłuszeństwu Ojcu i przyjęciu męczeńskiej śmierci, która zbawia świat ${ }^{30}$.

\section{IMMANENCJA BOGA A NATURA LUDZKIEGO POZNAWANIA}

Mimo rozlicznych historycznych i ewolucyjnych koncepcji Boga skłaniam się tu raczej do poglądu, że tylko ograniczenia ludzkiego pojmowania i nasza empirycznie ukształtowana wyobraźnia czynią Boga bytem historycznym - podlegającym „liniowej ewolucji”. W naszym świecie zmienność - a tym samym czas, którego ta zmienność (ruch) jest, jak ujął to Arystoteles, „substratem” - jest czymś naturalnym i oczywistym. Jeśli chodzi jednak o Boga, czas zaczyna być bardzo problematyczny. Klasyczne pytanie brzmi: czy Bóg stworzył świat w czasie czy wraz z czasem? Sprowadza się ono w zasadzie do pytania: czy Bóg jest bytem zmiennym i czasowym czy też Jego bytowanie ma miejsce poza czasem i jest wolne od wszelkiej zmienności? Trudno dać na to jednoznaczną odpowiedź.

30 K. Rahner, H. Vorgrimler, Mały słownik teologiczny, Instytut Wydawniczy Pax, Warszawa 1987, 175. 
Można podejrzewać, że ewentualna zmienność Boga ma radykalnie odmienny charakter od zmienności (ewolucyjności) zachodzącej w świecie stworzonym. Być może - choć dla nas to paradoksalne ruch w Bogu odbywa się poza czasem. Jest jakimś różnicowaniem się Boskiej Istoty, ale - patrząc z perspektywy „naszego” czasu - dokonanym pierwotnie (odwiecznie). To różnicowanie - jeśli przyłożyć do niego miarę stworzenia - miałoby bardziej "geometryczny” niż temporalny charakter. Tak jak niektórzy astrofizycy i kosmologowie mówią - moim zdaniem niesłusznie ${ }^{31}$ - o „wszechświecie blokowym", można by mówić - już z większym prawdopodobieństwem adekwatności - o „blokowej naturze Boga”, czyli o pewnej aczasowej Jego „ewolucji”, która oznacza odwieczne zróżnicowanie Jego natury. Zdaniem Hegla w odniesieniu do Boga „należy oddalić w ogóle każde określenie czasu, czy to trwania, czy to - [bycia] Teraz, i zatrzymać tylko prosta myśl o tym, co inne - prosta myśl, albowiem to, co inne, jest abstrakcjq"32.

Próbując jakoś oddać tę trudną do pojęcia dynamikę Boga, odwołam się jeszcze do innych słów Hegla, w których opisuje on stan buddyjskiej medytacji: „Ja nie jest martwym spokojem, lecz ruchem, ale nie ruchem, który nazywa się zmianą, lecz wiecznym ruchem, wieczną przejrzystością $\mathrm{w}$ sobie samym"33. Jak duże trudności ma Hegel z określeniem ruchu właściwego Bogu (a trzeba powiedzieć, że są to trudności zupełnie obiektywne) widać choćby z rozwijanej przez niego dialektyki różnicy i tożsamości. Otóż Bóg jako duch jest procesem, ruchem i życiem ${ }^{34}$, co - w świetle wspomnianej tu dialektyki - oznacza, że „Bóg jako to, co od niego odróżnione, ale w taki sposób, że to, co odróżnione, jest samo w sobie i dla siebie cata jego idea, tak że te dwa określenia są również dla siebie nawzajem tym

31 Co uzasadniam w książce: M. Łagosz, Realność czasu, Wrocław 2007.

32 G.W.F. Hegel, Wykłady z filozofii religii, t. 2, dz. cyt., 260.

33 G.W.F. Hegel, Wykłady z filozofii religii, t. 1, dz. cyt., 407.

34 Tamże, 232-233. 
samym, tą tożsamościa (...) te różnice znoszą się o tyle, o ile odróżnianie jest tak samo zakładaniem różnicy jako różnicy, która różnicą nie jest, i w ten sposób jedno w drugim jest u siebie samego" 35 . Próbując jakoś usprawiedliwić te słowa, można by pójść po linii epistemicznej i rozumieć je tak, że pewne momenty w naturze Boga są wprawdzie poznawczo odróżnialne, lecz same w sobie w żaden sposób nie są one różne, a tym bardziej - rozdzielne. Tyle tylko, że gubi się tu nam kontekst ontologiczny, o który głównie chodzi. Zamiast ruchu Boga (czy w Bogu) dostajemy ruch naszego myślenia o Bogu, które odróżnia.

$\mathrm{Z}$ jednej strony mamy intuicję, że byt absolutny nie powinien podlegać warunkowi czasu, tj. być zmiennym w zwykłym sensie przybierania różnych stanów w różnych momentach czasowych, a z drugiej: jeśli Bóg stwarza czasowy wszechświat i wchodzi z nim $\mathrm{w}$ relację, to tym samym wydaje się, iż Jego bytowanie w ten czas światowy jakoś musi być włączone. Nie znaczy to jednak, że Bóg jest w jakimś stopniu zależny od stworzenia. Teologowie uznają zazwyczaj, że relacja jest tu zdecydowanie asymetryczna: stworzony świat jest zależny od Absolutu, lecz nie odwrotnie. Bóg w żaden sposób nie zależy od stworzenia i w tym sensie relacja stwórcza „od strony Boga” nie jest realna. Św. Tomasz przedstawia następująca analogię dla tej sytuacji: poznawany przedmiot nie uczestniczy realnie w swoim poznaniu - akt poznania pozostaje po stronie podmiotu. Przedmiot poznania nie jest zatem w relacji dlatego, że on się do czegoś odnosi, lecz dlatego, że poznający odnosi się do niego.

W myśli chrześcijańskiej objawienie i zbawienie jest wejściem Boga samego w historię stworzonego przez Niego świata. Nawet już samo stworzenie ustawia Boga w kontekście historycznym, gdyż jest On „początkodawcą” historii. „Ale - jak pisze Karl Rahner - nie jest łatwo pogodzić takie roszczenie do absolutności [roszczenie chrześcijaństwa do bycia religią o absolutnej wartości - M.Ł.] z jednoczesnym

35 Tamże, 233. 
głoszeniem przez chrześcijaństwo, że jest rzeczywistością historyczną. Wydaje się, że to, co historyczne, nie może z samej definicji rościć sobie żadnych pretensji do jakiejkolwiek absolutności" ${ }^{36}$. Przy czym wątpliwość ta odnosi się nie tylko do chrześcijaństwa jako religii, ale i do samego Boga: „Można wysunąć zarzut - pisze dalej niemiecki teolog - że to, co historyczne, nie może być Bogiem, a to, co boskie, nie może być historyczne. To, co historyczne, jest bowiem zawsze czymś konkretnym, szczegółowym, czymś indywidualnym, umieszczonym w szerszym kontekście. Natomiast Bóg jest pierwotną podstawą i otchłanią każdej rzeczywistości, tym, który zawsze znajduje się poza wszystkim, co uchwytne"37. Uznanie jednak tego ostatniego nie pozostaje $w$ konflikcie $z$ tym, iż jako pierwotna podstawa i zarazem wszechmocna (w granicach swojej absolutnej wolności) Wola, Bóg i Jego dzieło zbawienia mogą jawić się historycznemu człowiekowi właśnie jako historyczne. Ponieważ jednak dochodzi tu do głosu różnica między immanencją (tym, czym Bóg jest sam w sobie w swej ahistoryczności) a transcendencją (tym, że Bóg objawia się człowiekowi w swej historyczności), wypada powtórzyć za Rahnerem: „Pytanie, czy i w jakim sensie może istnieć historia objawienia i zbawienia, jest więc jednym z najtrudniejszych i najbardziej podstawowych pytań chrześcijaństwa" 38 . Koncepcja Boga, który jest ahistoryczny $i$ historyczny zarazem, wprowadza nas - by posłużyć się sformułowaniem Rahnera - w swoistą dialektykę „między obecnością Boga jako dającego siebie w absolutnym samo udzieleniu siebie a nieobecnością Boga jako zawsze pozostającego świętą tajemnicą"39. Tak więc zagadnienie (a)historyczności Boga ma także swój aspekt epistemiczny. Spróbujmy zatem zmierzyć się $\mathrm{z}$ tym problemem.

36 K. Rahner, Podstawowy wykład wiary, dz. cyt., 119.

37 Tamże.

38 Tamże, 120.

39 Tamże, 121. 
Z punktu widzenia chrześcijańskiej doktryny religijnej można powiedzieć tak: „czysta natura” Boga, tj. Jego natura rozumiana poza „wejściem” Chrystusa w świat człowieka (niezależnie od wcielenia) jest ahistoryczna i w zasadniczym sensie aczasowa. Oznacza to na przykład, że troistość boskiej natury w żaden sposób nie powinna być rozumiana jako proces „trojenia się” Boga-Jedni w czasie. Uhistorycznienie przez człowieka natury Boga ma swe źródło nie tyle w boskiej naturze, co raczej wiąże się z naturą stworzenia, które nie może osiągnąć stopnia doskonałości niezmiennego w swej naturze Absolutu. Można powiedzieć, że religia przedstawia swe treści jako historyczne (i sama - jako po części przynajmniej dzieło człowieka jest historyczna), co nie przeszkadza, aby na najogólniejszym poziomie ontologicznym traktować Boga ahistorycznie - „aczasowo” $\mathrm{w}$ takim sensie, $\mathrm{w}$ jakim odwieczne bytowanie Boga przeciwstawia się czasowości wszechświata stworzonego, którą Platon nazywał - przypomnijmy - „ruchomym obrazem wieczności”. Przy tym ujeciu pojawia się wprawdzie problem rozdźwięku między religijnym „obrazem” a prawdziwą naturą Boga i może zachodzić podejrzenie, $\dot{z}$ e religia staje się fałszem lub - w najlepszym razie - uproszczeniem ontologicznym. Aby tego uniknąć, należałoby - być może - odwołać się do dwóch porządków: porządku naturalnego, w którym rządzi organizowana czasowo przyczynowość „niższa” (fizyczna) i reżimu supranaturalnego, dla którego właściwa jest przyczynowość - czy też - by pozbyć się słownej nawet zbieżności z przyczynowością fizyczną - determinacja „wyższa”, realizująca się poza czasem. Uznawane zaś w religii chrześcijańskiej wcielenie można by traktować jako „zstąpienie Boga w czas”40 - swoiste „rozszczepienie Jego natury”, gwoli nawiązania kontaktu z czasowym stworzeniem. W ten sposób

40 W teologii dogmatycznej mówi się, że samotranscendencja świata stworzonego w kierunku Boga domaga się Jego współdziałania. To ostatnie zaś polega na samoudzieleniu się Boga w stworzeniu oraz we wcieleniu Boskiego Logosu. Tu wkraczamy zaś w historię zbawienia, „gdzie Bóg w czasoprzestrzeni »jest obecny « absolutnie i nieodwołanie” (K. Rahner, H. Vorgrimler, Mały słownik teologiczny, dz. cyt., 533). Jednocześnie utrzymuje się, że 
religia, przedstawiając Boga jako byt historyczny, nie pozostawałaby w konflikcie $\mathrm{z}$ absolutną niehistorycznością Jego istotowej egzystencji.

Zamiast mówić - jak ująłem to wyżej - o rozszczepieniu natury Boga wkraczającego w stworzony kosmos, lepiej byłoby mówić o przejawianiu się człowiekowi ahistorycznego w swej istocie Boga jako egzystencji historycznej. Czy ujęcie takie nie grozi jednak na poziomie epistemicznym pojawieniem się szkodliwej koncepcji „podwójnej prawdy”? Otóż, zdaje się, że nie. „Podwójna prawda” jest szkodliwa, gdy odnosi się do jednego i tego samego poziomu ontycznego. Tak jest, gdy ktoś na przykład mówi, że w naszym świecie pozabiologiczne poczęcie Jezusa przez Maryję jest prawdą z religijnego, a fałszem z przyrodoznawczego punktu widzenia. Logika podpowiada bowiem, że w odniesieniu do jednego i tego samego poziomu (aspektu) bytu, któryś z tych punktów widzenia jest fałszywy. W naszej interpretacji nic takiego jednak nie zachodzi: Bóg pozostaje ahistoryczny w swej supranaturalnej domenie, przejawiając się w historii ludzkiej, zgodnie z porządkiem stworzonej czasowości. Jezus Chrystus narodził się, umarł na Krzyżu i zmartwychwstał w liniowym następstwie tych kolejnych zdarzeń, co nie przeczy temu, że Bóg Trójjedyny w swej istocie procesom historycznym nie podlega. Analogicznie do tego, jak kolorowy dla oczu świat sam w sobie koloru nie posiada ${ }^{41}$.Wątek jednoczesnej ahistoryczności oraz historyczności Boga (zbawienia) można zatem podsumować słowami Ratzingera wypowiedzianymi w kontekście problemu „dwóch prawd”: „Obiektywna jedność prawdy pozostaje oczywiście w mocy, jako że ograniczenie ważności danego twierdzenia dokonuje się na właściwej mu płaszczyźnie"42.

Zagadnienie historyczności zbawienia i objawienia nie wydaje się zatem aż tak trudne, jak wskazuje to Rahner. „Podwojenie światów”

to samoudzielenie się Boga nie powoduje, iż staje się on „istotowym momentem” bytu skończonego. Tamże, 531.

41 Analogia jest tu o tyle niedokładna, że zarówno oczy, jak i oglądane nimi przedmioty należą do tego samego poziomu bytu fizycznego.

42 J. Ratzinger, Rozumienie objawienia i teologia historii według Bonawentury, dz. cyt., 229. 
na świat absolutnej boskiej immanencji, w której odwiecznie wszystko ma swój aktualny byt, oraz ludzkiej transcendencji względem Boga, która rozwija się historycznie, nie stwarza większych interpretacyjnych problemów - a w każdym razie nie większe niż istnienie transcendentnych względem siebie Boga i stworzenia. Stworzenie nie jest Bogiem, a historyczność (czasowość) jest jednym z tych momentów, które odróżnia je od Niego. Jest Bóg w sobie i Bóg dla człowieka Bóg wchodzący w historię poprzez rozciągnięte w czasie objawienie i zbawienie. To jest jeden i ten sam Bóg. Skoro ma On moc, aby stworzyć czas (historię), to może też się w niej pojawić - stać się historyczny w wynikającym z Jego absolutnej miłości akcie kenozynie przestając zarazem być w swej istocie bytem „wszechaktualnym”, tj. aczasowym. Po prostu w ludzkiej transcendencji to, co u Boga występuje „w aczasowym zwinięciu”, rozwija się w ciąg historycznych zdarzeń. Ahistoryczny Bóg staje się historyczny, bo tylko w tej postaci może wejść w relację z człowiekiem, którego stworzył jako byt historyczny właśnie. Gdyby nie to brzemię czasowości, stworzenie równe byłoby Bogu i zamiast transcendencji Boga mielibyśmy panteizm.

\section{ZAKOŃCZENIE}

Boga ujmujemy jako początek i koniec (Alfę i Omegę) stworzonego świata; sam jednak początku ani końca nie posiada. Pozostaje wszak - nierozstrzygnięte wyżej ${ }^{43}$ - pytanie, czy jest tak dlatego, że - jako byt pierwotny istnieje On odwiecznie („odnieskończenie” i „donieskończenie" 44 ), tj. wszechczasowo czy też w ogóle poza czasem.

43 Czy w ogóle rozstrzygalne?

44 Terminologię tę zaczerpnąłem z książki Katarzyny Polus-Rogalskiej, Problem przemian przyrodniczych w filozofii przedsokratejskiej. Traktat ontologiczno-epistemologiczny. Logiczno-lingwistyczne dopełnienie idei, Fundacja Instytut Wydawniczy „Maximum”, Kraków 2018, a znaczy ona odpowiednio: istnienie bez początku oraz istnienie bez końca. 
Należy przyjąć, że Bóg istnieje poza czasem stworzonym (kosmicznym) - stwarza wszak świat wraz z tym czasem. Jeśli jednak uznamy za Arystotelesem, że „substratem” czasu jest ruch (szeroko pojęta zmienność) i nie odmówimy Bogu wszelkiej dynamiki (a trudno to zrobić i uznać tym samym, że jest On „skostniały” pozbawiony wewnętrznego życia ${ }^{45}$ ), to będziemy musieli przypisać Mu także pewną swoistą charakterystykę „czasową”. („Czasową” piszę $\mathrm{w}$ cudzysłowie, gdyż w żadnym razie nie może chodzić tu o czasowość znaną nam ze świata stworzonego, w którym ruch generowany jest poprzez związki przyczynowe). W Bogu - jak można się domyślać - realizuje się zupełnie inna niż kauzalna zasada ruchu, stąd też i struktura Jego zmienności (przyjmuję, że nasze pojęcie czasu odzwierciedla strukturę zmienności świata stworzonego) musi być radykalnie odmienna. Ten domniemany rodzaj „Boskiej czasowości" można nazwać czasem absolutnym i uznać, że przypomina on coś, co z naszej ludzkiej perspektywy określiłbym za Heglem teraźniejszą obecnością lub po prostu - wiecznością. Zwykły czas kosmiczny „podlega prawu skończonego przemijania”46; wieczność zaś zawiera w sobie czasowość, ale taką - jak ujmuje to Tillich „w której przeszłość i przyszłość są złączone ze sobą w wiecznej teraźniejszości, ale nie zanegowane"47. Można to interpretować tak, że "po dokonaniu się czasu” kosmiczna czasowość (to wszystko, co wydarzyło się w dziejach świata i człowieka) zostaje zachowana i włączona w wieczny porządek nieprzemijającej teraźniejszości - niejako „zblokowana” w teraźniejszej obecności Boga. Być może pomocna - choć z pewnością bardzo ograniczona - byłaby tu analogia do "czasu zgeometryzowanego", jaki mają na myśli niektórzy astrofizycy i kosmologowie, mówiąc o „wszechświecie blokowym”48.

45 W tym punkcie „dialektycy” mają - moim zdaniem - zdecydowana przewagę nad „metafizykami" - co zresztą uwidaczniają rozważania prowadzone powyżej.

46 P. Tillich, Pytanie o Nieuwarunkowane, dz. cyt., 126.

47 Tamże.

48 Patrz wyżej: 3. Dialektyczny punkt widzenia. Hegel. 


\section{BIBLIOGRAFIA}

Arystoteles, Fizyka, tłum. z gr. K. Leśniak, w: tenże, Dzieła wszystkie, t. 2, PWN, Warszawa 1990.

Balthasar von H.U., Teologika 3. Duch Prawdy, Wydawnictwo WAM, Kraków 2005.

Hegel G.W.F., Nauka logiki, t. 1, PWN, Warszawa 1967.

Hegel G.W.F., Wyktady z flozofii religii, t. 1, Wydawnictwo Naukowe PWN, Warszawa 2006.

Hegel G.W.F., Wyktady z filozofi religii, t. 2, Wydawnictwo Naukowe PWN, Warszawa 2007.

Łagosz M., Realnośćczasu, Wydawnictwo Uniwersytetu Wrocławskiego, Wrocław 2007.

Polus-Rogalska K., Problem przemian przyrodniczych w filozofii przedsokratejskiej. Traktat ontologiczno-epistemologiczny. Logiczno-lingwistyczne dopetnienie idei, Fundacja Instytut Wydawniczy „Maximum”, Kraków 2018.

Rahner K., Podstawowy wyktad wiary. Wprowadzenie do pojęcia chrześcijaństwa, Instytut Wydawniczy PAX, Warszawa 1987.

Rahner K., Vorgrimler H., Maty stownik teologiczny, Instytut Wydawniczy Pax, Warszawa 1987.

Ratzinger J., Rozumienie objawienia i teologii historii wedtug Bonawentury, Wydawnictwo KUL, Lublin 2014.

\section{THE PROBLEM OF THE (A)TEMPORALITY OF GOD}

Abstract. This paper considers the problem of the (a)temporality (un-changeability) of God, which is analysed from a dialectical point of view - especially from an Hegelian perspective. The conclusion we argue for is that the temporality (changeability) of God is very different from the temporality of the physical world because the former is not determined by the principle of causality.

Keywords: God, changeability, unchangeability, historicity, metaphysical nature, temporality, timelessness, spirit, identity, difference.

MAREK ŁAGOSZ

marek.lagosz@uwr.edu.pl

Instytut Filozofii Uniwersytetu Wrocławskiego

ul. Koszarowa 3, 51-149 Wrocław

ORCID: 0000000185024922

DOI: 10.21697/spch.2020.56.1.04 